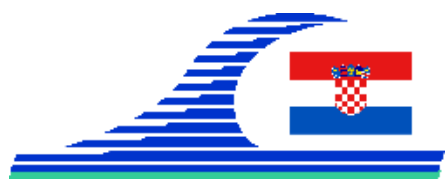

\title{
Towards an understanding and operational early warning of the Adriatic meteotsunamis: Project MESSI
}

\section{Jadranka ŠEPIĆ ${ }^{1}$, Ivica VILIBIĆ ${ }^{1 *}$, Gordana BEG PAKLAR ${ }^{1}$, Vlado DADIĆ ${ }^{1}$, Clea DENAMIEL ${ }^{1}$, Natalija DUNIĆ ${ }^{1}$, Tomislav DŽOIĆ ${ }^{1}$, Miro GAČIĆ ${ }^{2}$, Kristian HORVATH ${ }^{3}$, Damir IVANKOVIĆ ${ }^{1}$, Dalibor JELAVIĆ ${ }^{1}$, Hrvoje KALINIĆ $^{4}$, Žarko KOVAČ ${ }^{1}$, Vedrana KOVČEVIĆ ${ }^{2}$, Toni MAŠĆE ${ }^{1}$, Frano MATIĆ $^{1}$, Iva MEĐUGORAC ${ }^{5}$, Hrvoje MIHANOVIĆ ${ }^{1}$, Sebastian MONSERRAT ${ }^{6}$, Stipe MUSLIM ${ }^{1}$, Alexander RABINOVICH ${ }^{7,8}$, Maja TELIŠMAN-PRTENJAK ${ }^{5}$, Martina TUDOR ${ }^{3}$}

1. Institute of Oceanography and Fisheries, Šetalište I. Meštrovića 63, 21000 Split, Croatia.vilibic@izor.hr

2. Istituto Nazionale di Oceanografia e di Geofisica Sperimentale - OGS, Borgo Grotta Gigante 42/C, 34010 Sgonico, Italy.

3. Meteorological and Hydrological Service, Grič 3, 10000 Zagreb, Croatia

4. Faculty of Science, University of Split, Ruđera Boškovića 33, 21000 Split, Croatia

5. Faculty of Science, University of Zagreb, Horvatovac 95, 10000 Zagreb, Croatia

6. Department of Physics, University of the Balearic Islands, Ctra.Valldemossa, $\mathrm{km}$. 7.5, Palma de Mallorca, Spain.

7. P.P. Shirshov Institute of Oceanology, Russian Academy of Sciences, 36 Nakhimovsky Pr., Moscow, Russia.

8. Fisheries and Oceans Canada, Institute of Ocean Sciences, 9860 W. Saanich Rd., Sidney, BC, Canada

\begin{abstract}
:
The paper presents the architecture and major achievements of the project MESSI, aiming to build a reliable prototype of a meteotsunami warning system based on realtime measurements, operational atmosphere and ocean modelling and real-time decision-making process, using knowledge acquired from analysis of historical destructive events. A number of tide gauge and microbarograph stations were installed in the middle Adriatic area, whilst synoptic patterns and numerical weather prediction mesoscale models have been examined to establish connection between atmospheric forcing and meteotsunami waves. Project outcomes will be highly beneficial for endangered coastal communities, in a sense of rising timely alarms, for planning of construction works along the coastline (roads, marinas, piers, etc.), for the navigation safety, educating people and raising awareness in endangered areas.
\end{abstract}

Keywords: Natural marine hazards, tsunamis, real-time observations, early warning system, Adriatic Sea

https://dx.doi.org/10.5150/cmcm.2017.033 
Mediterranean rocky coasts:

Features, processes, evolution and problems

\section{Introduction}

Meteotsunamis or meteorological tsunamis are atmospherically-generated long ocean waves in a tsunami frequency band (MONSERRAT et al., 2006). Travelling air pressure disturbances are the most common generator of meteotsunamis, where the energy is transferred from the atmosphere to the ocean through a number of resonances, of which most common are Proudman resonance (PROUDMAN, 1929) and harbour resonance (RABINOVICH, 2009). At the top of a harbour these sea level oscillations can range for several metres and can flood coastal areas (VUČETIĆ et al., 2009), damage coastal infrastructure (JANSÀ et al., 2007; PATTIARATCHI \& WIJERATNE, 2015), and injure and kill the people (HIBIYA \& KAJIURA, 1982; BECHLE et al., 2016).

Meteotsunamis has been documented to occur worldwide, while being particularly destructive in micro-tidal regions, where the coasts and the infrastructures are not adapted to large and rapid sea level oscillations. Still, no real-time warning system has been established in the world, aside the qualitative warning for the area of the Balearic Islands operated by AEMET Meteo Service, by examining synoptic patterns and searching manually for conditions having a potential to generate meteotsunamigenic atmospheric disturbances (JANSÀ et al., 2007). The eastern Adriatic shoreline is found particularly vulnerable for meteotsunamis, where a number of events occurred in the last decades over the whole coastline (VILIBIĆ \& ŠEPIĆ, 2009). For that reason, MESSI project has been developed, trying to better understand the phenomenon and to develop the procedures necessary for providing timely warnings to authorities and coastal population.

\section{Project MESSI: The architecture and major achievements}

The main objective of the MESSI project (www.izor.hr/messi) is to build a reliable prototype of a meteotsunami warning system, using knowledge acquired from analysis of historical destructive events. The prototype will be based on real-time measurements, operational atmosphere and ocean modelling and real time decision-making process.

To achieve the objective, the project has been executed through nine modules, which are covering research, technological and operational issues of a meteotsunami warning system:

- Task 1. Assessment of historical Adriatic meteotsunamis

- Task 2. Design and construct a meteotsunami monitoring station prototype

- Task 3. Installation of a meteotsunami research and warning network

- Task 4. Estimate occurrence rate of meteotsunamis in the past, present and future climate

- Task 5. Mapping of meteotsunami hazard and creation of meteotsunami warning matrices.

- Task 6. Setup of operational atmospheric and ocean models

- Task 7. Set up a prototype of warning system 
Mediterranean rocky coasts:

Features, processes, evolution and problems

- Task 8. Create dynamic web content with a meteotsunami hazard forecast

- Task 9. Dissemination towards potential users

The research issues encompassed the examination of past Adriatic meteotsunami events, like the one occurred on 25 and 26 June 2014 (ŠEPIĆ et al., 2016a). Meteotsunamis were particularly strong in six harbours and bays along the eastern Adriatic coast, while the strongest events occurred in Vela Luka (Korčula Island), a known meteotsunami hot-spot, where waves reached height of $3 \mathrm{~m}$, and in Rijeka dubrovačka Bay, where strong $5 \mathrm{~m} / \mathrm{s}$ currents accompanied $2.5 \mathrm{~m}$ high waves. The event has been generated by a series of individual air pressure disturbances characterized by pronounced rates of air pressure change, limited spatial extent and high temporal variability.

Furthermore, connecting synoptic patterns with meteotsunami events were also established by constructing of a meteotsunami synoptic index (ŠEPIĆ et al., 2016b). The index has been constructed from atmospheric reanalysis fields, for which operational forecast is valid for a week, therefore allowing for a fair forecasting of meteotsunami events by using global forecast products provided by European Centre for Middle-range Forecast (ECMWF).

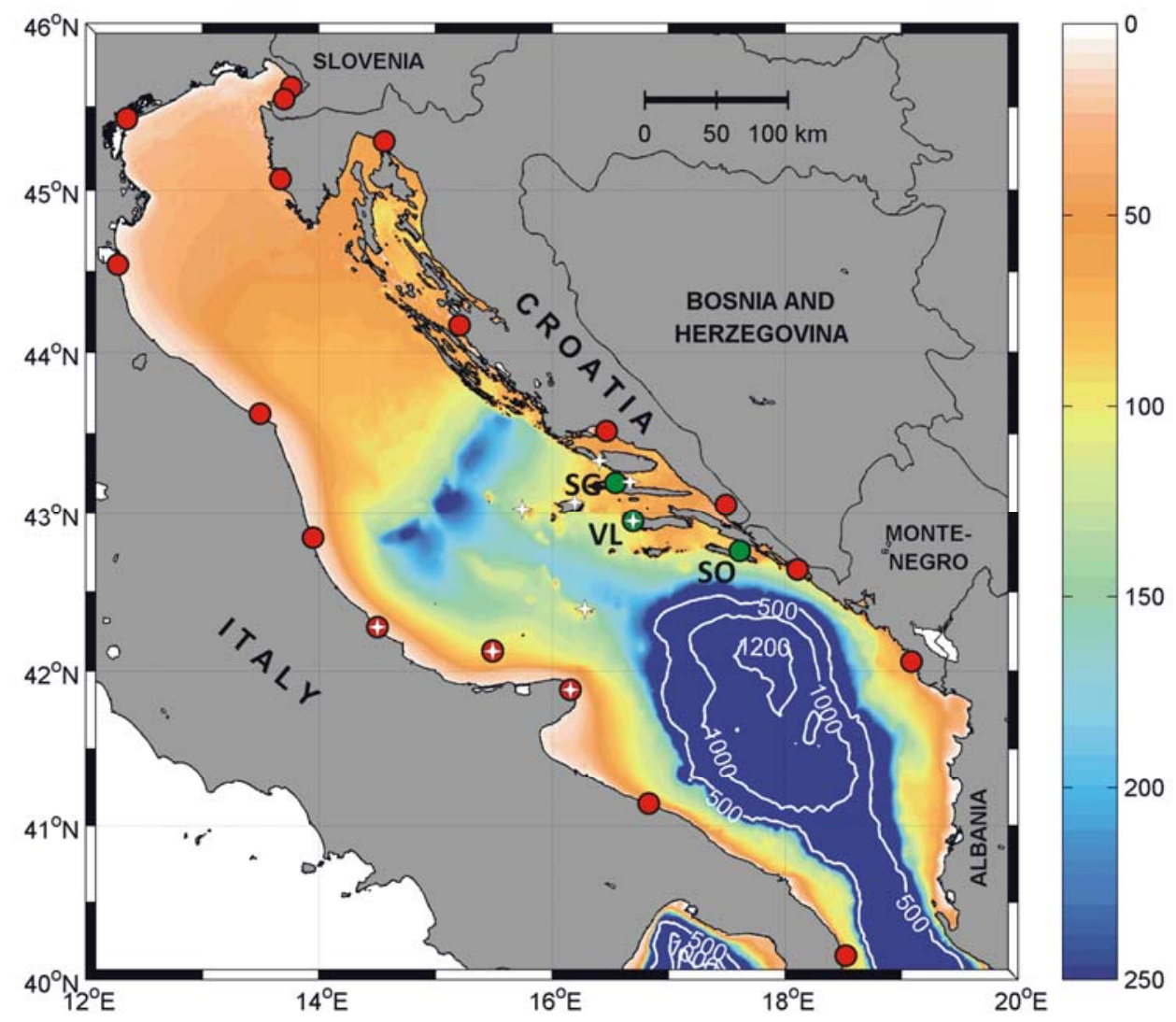

Figure 1. The bathymetry of the Adriatic Sea, with operating tide gauges (circles) and microbarographs (stars). New tide gauge stations (SG - Stari Grad, VL - Vela Luka, SO - Sobra) installed within the MESSI project are marked by green. 
Mediterranean rocky coasts:

Features, processes, evolution and problems

Technological part of the project includes the development and installation of three tide gauge and nine microbarograph stations along the central Adriatic, shown in Fig. 1. Microbarograph stations are located at both coastlines, to allow for timely detection of a meteotsunamigenic atmospheric disturbance. The tide gauge stations are composed of radar instruments OTT RLS with sampling rate of $20 \mathrm{~s}$ and averaging values over 1 min. The example of the measurements at Vela Luka and Sobra stations is provided in Fig. 2. As the Vela Luka tide gauge is positioned deeply inside the bay known to have strong amplification rates of the incoming long ocean waves (VUČETIĆ et al., 2009), its record contains eigenoscillations of the Vela Luka Bay. By contrast, high-frequency oscillations at the Sobra tide gauge are much weaker, due to the bathymetry and position of the tide gauge inside a wide bay with low amplification rates.

Finally, the meteotsunami hazard is going to be mapped by using Weather Research and Forecasting Model (WRF), which forces ROMS and ADCIRC/SELFE ocean models, having high resolution in the eastern coastal area. This modelling system allows for probabilistic forecasting of the meteotsunami hazard at hot spot locations along the eastern Adriatic coastline, by comparing the forecasts with an atlas of pre-simulations covering all possible meteotsunami scenario developments.

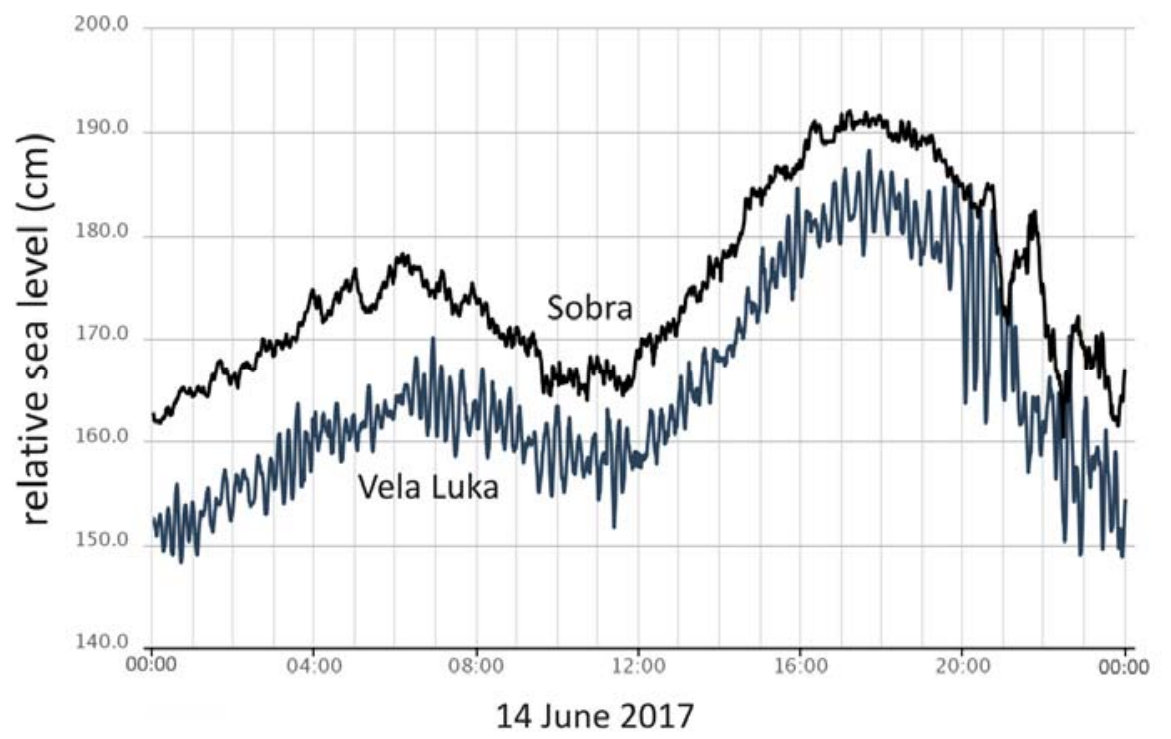

Figure 2. Sea level series measured at Sobra (SO) and Vela Luka (VL) on 14 June 2017.

\section{Potential users}

The MESSI early warning system will be of great interest for a number of end users. At first, the Institute of Oceanography and Fisheries (IOF) has a strong interest to fulfil the project activities, as it is foreseen as future operational oceanographic service for the Adriatic marine hazards. Next, Meteorological and Hydrological Service will benefit from investigation a process which require non-standard meteo measurements, thus 
Mediterranean rocky coasts:

Features, processes, evolution and problems

setting new standards for its operational forecast. The Mediterranean, European and world community in operational oceanography will benefit, as meteotsunamis are perceived as an underrated hazard that occur throughout the oceans (PATTIARATCHI \& WIJERATNE, 2015). Various national ministries and civil protection agencies should be interested for project products, as being which are potential governmental users and possible organisers/sponsors for the establishment and maintenance of an operational oceanography centre. That also includes an integration of meteotsunami hazard and risk into integrated coastal zone management (ICZM) plans, produced at both national and local level. For latter, local authorities (counties, cities, municipalities) should be particularly interested, as strongest meteotsunamis in the Adriatic typically occur at particularly vulnerable locations (e.g. Vela Luka, Stari Grad), normally in the summer season which is the high tourist season. Possibility to issue a meteotsunami warning is of high interest to local authorities, while an education of local population what to expect and how to behave in a case of a strong meteotsunami is a prerequisite for raising the awareness on this rare but destructive phenomenon.

\section{References}

BECHLE, A.J., WU, C.H., KRISTOVICH, D.A.R., ANDERSON, E.J., SCHWAB, D.J., RABINOVICH, A.B (2016). Meteotsunamis in the Laurentian Great Lakes. Scientific Reports, Vol. 6, 37832, http://dx.doi.org/10.1038/srep37832

HIBIYA, T., and KAJIURA, K. (1982), Origin of the Abiki phenomenon (a kind of seiche) in Nagasaki Bay. Journal of the Oceanographic Society of Japan, Vol. 38, pp. 172-182, http://dx.doi.org/10.1007/BF02110288

JANSÀ, A., MONSERRAT, S., GOMIS, D. (2007). The rissaga of 15 June 2006 in Ciutadella (Menorca), a meteorological tsunami. Advances in Geosciences, Vol. 12, pp. 1-4, http://dx.doi.org/10.5194/adgeo-12-1-2007

PATTIARATCHI, C.B., WIJERATNE, E.M.S. (2015). Are meteotsunamis an underrated hazard?. Philosophical Transactions of the Royal Society A, Vol. 373, 20140377, http://dx.doi.org/10.1098/rsta.2014.0377

PROUDMAN, J. (1929). The effects on the sea of changes in atmospheric pressure. Geophys. Suppl. Mon. Not. R. Astron. Soc., Vol. 2(4), pp. 197-209.

RABINOVICH, A.B. (2009). Seiches and harbour oscillations, In Handbook of Coastal and Ocean Engineering (ed. KIM, Y.C.), World Scientific, Singapore

ŠEPIĆ, J., MEĐUGORAC, I., JANEKOVIĆ, I., DUNIĆ, N., VILIBIĆ, I. (2016a). Multi-meteotsunami event in the Adriatic Sea generated by atmospheric disturbances of 25-26 June 2014. Pure and Applied Geophysics, Vol. 173, pp. 4117-4138, http://dx.doi.org/10.1007/s00024-016-1249-4

ŠEPIĆ, J., VILIBIĆ, I., MONSERRAT, S. (2016b). Quantifying the probability of meteotsunami occurrence from synoptic atmospheric patterns. Geophysical Research Letters, Vol. 43, pp. 10377-10384, http://dx.doi.org/10.1002/2016GL070754 
Mediterranean rocky coasts:

Features, processes, evolution and problems

VILIBIĆ, I., ŠEPIĆ, J. (2009). Destructive meteotsunamis along the eastern Adriatic coast: Overview. Physics and Chemistry of the Earth, Vol. 34, pp. 904-917, http://dx.doi.org/10.1016/j.pce.2009.08.004

VUČETIĆ, T., VILIBIĆ, I., TINTI, S., MARAMAI, A. (2009). The great Adriatic flood of 21 June 1978 revisited: an overview of the reports. Physics and Chemistry of the Earth, Vol. 34, pp. 894-903, http://dx.doi.org/ 10.1016/j.pce.2009.08.005 